\title{
EEG SPECTRAL COHERENCE INTER AND INTRAHEMISPHERIC DURING CATCHING OBJECT FALL TASK
}

\author{
Cláudio Elidio Portella1,5, Julio Guilherme Silva1,4, Sergio Machado', \\ Bruna Velasques', Victor Hugo do Vale Bastos ${ }^{1,4,5}$, Camila Ferreira-Vorkapic', \\ Patrícia Terra ${ }^{3}$, Vladimir Lopes ${ }^{3}$, Mauricio Cagy', Eduardo de Carvalho', \\ Marco Orsini ${ }^{4,5}$, Luis Basile ${ }^{6}$, Roberto Piedade ${ }^{1}$, Pedro Ribeiro ${ }^{1,2,3}$
}

\begin{abstract}
The aim of the present study was to evaluate coherence measures at Theta through qEEG during the accomplishment of a specific motor task. The sample consisted of 23 healthy individuals, both sexes, with ages varying between 25 and 40 years old. All subjects were submmitted to a specific motor task of cacthing sequences of falling balls. A three-way ANOVA was employed for the statistical analysis, which demonstrated main effects for the following factors: time, block and position. However, there was no interection between the factors. A significant and generalized coherence reduction was observed during the task execution time. Coherence was also diminished at the left frontal cortex and contralateral hemisphere of the utilizing limb (comparing to the right frontal cortex). In conclusion, these findings suggest a certain specialization of the neural circuit, also according to previous investigations. The inter-coherence reduction suggests a spatial inter-electrode dependence during the task, rather than a neuronal specialization.
\end{abstract}

KEY WORDS: coherence, neural specialization, qEEG, motor activity.

\begin{abstract}
Coerência espectral do eletrencefalograma inter e intra-hemisférica durante a tarefa de apreensão de um objeto em queda livre

RESUMO - O objetivo do presente experimento foi avaliar medidas de coerência na banda Teta através do EEGq durante a realização de uma atividade motora. A amostra constituiu-se de 23 sujeitos saudáveis, ambos os sexos, faixa etária entre 25 e 40 anos. Os sujeitos foram submetidos à tarefa motora de apreensão seqüencial de bolas em queda livre. Para análise estatística foi realizada uma ANOVA (Three-Way) que demonstrou efeito principal para os fatores: momento, tempo e posição. Porém não houve interação entre os fatores. Uma diminuição generalizada significativa da coerência ocorreu ao longo do tempo de execução da tarefa que também se apresentou reduzida no córtex frontal esquerdo, hemisfério contralateral ao membro utilizado (em comparação com o córtex frontal direito). Em conclusão, estes achados sugerem especialização do circuito neural que estão em consonância com experimentos prévios. A diminuição da coerência inter-hemisférica sugere uma dependência espacial inter-eletrodos durante a tarefa e não uma especialização neuronal.
\end{abstract}

PALAVRAS-CHAVE: coerência, especialização neural, EEGq, atividade motora.

The human being, during all its existance, experiences different learning processes, which promotes a performance improvement ${ }^{1}$. In all aspects of human motricity, it is awknoledged the relevance of identifying and acquiring sensory stimuli as essential factors in the preparation and adjustment of a motor $\mathrm{act}^{2}$. Certain cortex areas are known for their inte- gration capability. They are neither sensory, nor motor areas, instead they are integration regions, integrating sensory stimuli to motor centers ${ }^{3}$. In this contex, the prefrontal area, comprehending the non-motor anterior region of the frontal lobe, receives fibers from all cortex association areas ${ }^{4}$. Although there are still many doubts on the functional meaning of this

\footnotetext{
'Laboratório de Mapeamento Cerebral e Integração Sensório-motor, Instituto de Psiquiatria (IPUB), Universidade Federal do Rio de Janeiro, Rio de Janeiro RJ, Brasil (UFRJ); ${ }^{2}$ Departamento de Biociências da Atividade Física, Escola de Educação Física e Desportos (EEFD), UFRJ; ${ }^{3}$ Universidade Castelo Branco (PROCIHM); ${ }^{4}$ Curso de Fisioterapia da Fundação Educacional Serra dos Órgãos - FESO, Teresópolis, Rio de Janeiro RJ, Brasil; ${ }^{5}$ Curso de Fisioterapia UNIABEU; ${ }^{6}$ Departamento de Psiquiatria, Faculdade de Medicina, Universidade de São Paulo, São Paulo SP, Brasil (USP), Faculdade de Psicologia e Fonoaudiologia; ${ }^{7}$ Centro Brasileiro de Pesquisas Físicas - CBPF / Coordenação de Atividades Técnicas (CAT).
}

Received 6 April 2006, received in final form 21 September 2006. Accepted 13 October 2006.

Dr. Cláudio Elidio Almeida Portella - Rua Silva Teles 30 A / 208 - 20541-110 Rio de Janeiro RJ - Brasil. E-mail: itoito@click21.com.br 
area, clinical and experimental data have demonstrated some of its responsabilities: planning, maintainance of attention, strategies choices and behavioral inhibition ${ }^{5}$. Some studies suggest that the prefrontal area might also be involved with short-term memory ${ }^{6}$. Therefore, changes occuring in this brain area, as a function of motor reaction have interested reserchears for years ${ }^{7}$.

Each day a new paradigm is invented, in an effort to extend the current kwnoledge on interneural interaction during the production of a motor action. Electroencephalography (EEG) has provided investigators with new information about the motor and cognitive leaning mechanisms $\mathrm{s}^{8-9}$. Electroencephalographic variables have been analyzed regarding their strict relation with motor learning processes ${ }^{10}$. Coherence, defined as spectral power covariance among different brain areas, must receive attention, since it verifies the occurrence of co-activaion between two cortical areas ${ }^{12}$. In other words, coherence measures the correlation between pairs of signals as a frequency function ${ }^{11-13}$. Consequently, it measures connection processes among brain regions ${ }^{14}$. For example, a coherence reduction could be interpreted as an indication of specialization at certain cortical areas, appearing to act, therefore, as a neural tracer of new motor procedures ${ }^{15}$.

Since planning depends on the integration of diverse activities of diffent brain areas, the coherence analysis might be useful at trying to understand such cognitive ${ }^{11}$. Hence, the Theta band, with frequencies varying between 4 and $7 \mathrm{~Hz}$, was selected given its well documented relation to mental tasks, specifically those requiring sustained attention ${ }^{16}$. This band is also related to motor and other cognitive activities ${ }^{17-}$ ${ }^{18}$. Therefore, the present experiment aims at evaluating changes on electroencephalografic patterns, specifically coherence at Theta band. Such differences are compared at the following scalp regions: right frontal (RF), left frontal (LF) and inter-hemespheric (IH) during the catching of a falling object (ball). The study also tryes to analyze the differences in coherence between the pre and post balls' dropped and during the task execution phases.

\section{METHOD}

Sample - The sample was composed of 23 healthy individuals, both sexes, with ages varying between $25-40$ years. All subjects were graduating and undergraduating students of different health areas. Inclusion criteria were: absence of mental and physical illness (previous anamnese), right handed (Edinburgh ${ }^{19}$ ), and not be making use of any psychoactive nor psychotropic substance at the time of the study. All subjects were aware of the experimental proto- col and signed a consent form describing it. The entire experimental protocol was approved by the Ethics Committee of the Psychiatry Institute, at Federal University of Rio de Janeiro(IPUB/UFRJ).

Experimental procedure - At day and time previously scheduled, the subject arrived at the Brain Mapping and Sensory Integration Laboratory (IPUB/UFRJ) and was immediately informed (once again) of the entire protocol. All subjects seated comfortably in a sound and light-attenuated room with their forearms on a supine position, stabilized by an arm support made by a piece of wood. An electromagnetic system, composed of two solenoids were placed in front of the subjects, releasing (free falling) once at a time 8-cm tennis balls at a $40 \mathrm{~cm}$ height in the subjects' hands. After catching it, the ball was discharged by the subjects through forearm pronation and finger extension. Time interval between the ball falls was eleven seconds. Each released ball constitutes a trial and blocks were composed of fifteen trials. Therefore, the experiment had a total of six blocks, where each block lasted two and a half minutes with one-minute interval between them. Each interval favored recovery of the active limb, avoiding muscular fatigue.

Data acquisition - A sensor was placed exactly where the ball was released by the system, sending a signal of the ball fall to a Pentium III computer, and therefore, providing data analysis two seconds before and after the ball crosses the sensor. Data were collected with eyes closed in order to observe the cortex electrical activity without any external stimuli, minimizing possible visual artifacts. Electrodes were positioned according to the International 10 / 20 System (referred to linked earlobes with ground at FPZ). All electrode impedances were kept below $5 \mathrm{k} \Omega$. The signal was amplified with a gain of 22,000 , analogically filtered between $0.01 \mathrm{~Hz}$ (high-pass) and $100 \mathrm{~Hz}$ (lowpass), and sampled at $240 \mathrm{~Hz}$ using a Braintech-3000 ${ }^{\circledR}$ (EMSA-Medical Instruments, Rio de Janeiro, RJ, Brazil) EEG acquisition system. The EEG was recorded by means of the software ERP acquisition (Delphi $5.0^{\circledR}$, Borland-Inprise), developed at the Brain Mapping and Sensory Motor Integration Lab, employing the following digital filters: notch $(60 \mathrm{~Hz})$, high-pass of $0.3 \mathrm{~Hz}$ and low-pass of $25 \mathrm{~Hz}$. Visual inspection was employed for detection and elimination of artifacts. Eye-movement (EOG) artifact was monitored with a bipolar electrode montage using two 9-mmdiameter electrodes attached superior to and on the external cantus of the right eye.

Spatial localization of electrodes and frequency bands - Frontal area was selected for the analysis due to its acknowledged mechanisms of motivation, planning and execution of voluntary movements associated to this ${ }^{12-13}$. The following electrodes were combined: F7, F3, F8, F4 and FZ. Theta band, between 4 and $7 \mathrm{~Hz}$ was also selected due to its well documented relation with mental tasks, particularly, sustained attention ${ }^{16}$ and therefore motor and cognitive activity ${ }^{17,18}$. 


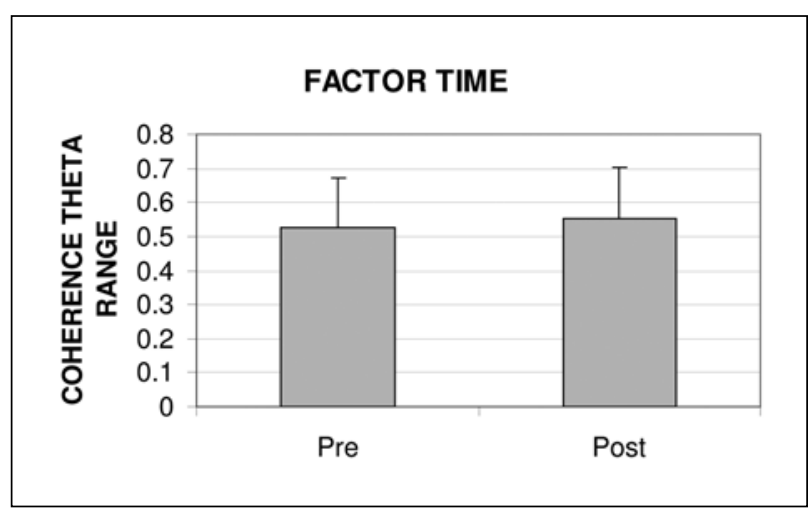

Fig 1. Relation of the coherence values at theta band in prefrontal region, between the time pre and post ball's fall for the system, during the execution of motor task.

Statistical analysis - Two statistical analyses were carried out. In the first analysis, a three-way ANOVA compared the factors: time, block and position. The factor position was subdivided as follows: 1 (left frontal hemisphere: F7F3; F7FZ E F3FZ), 2 (right frontal hemisphere: F8F4; F8FZ e F4FZ) e 3 (inter-hemispheric: F7F8; F3F4; F7F4 e F8F3). The factor time reflects the ball pre and post - releasing times, and the factor blocks reflects three blocks $(p \leq 0.05)$. Finally, a one-way ANOVA verified the differences in coherence measures between the combinations regarding the electrode pairs (F7F8 x F3F4; F8FZ x F4FZ; F7FZ x F3FZ).

\section{RESULTS}

In the first statistical analysis, that results demonstrated a main effect for the following factors: time $(p=0.012)$ (Fig 1), blocks 1 and $3(p=0.022)$ (Fig 2), position 1 and $2(p=0.001), 1$ and $3(p=0.000), 2$ and 3 $(p=0.000)$ (Fig 3$)$, not occuring interactions between the factors. In the analysis, regading the electrode

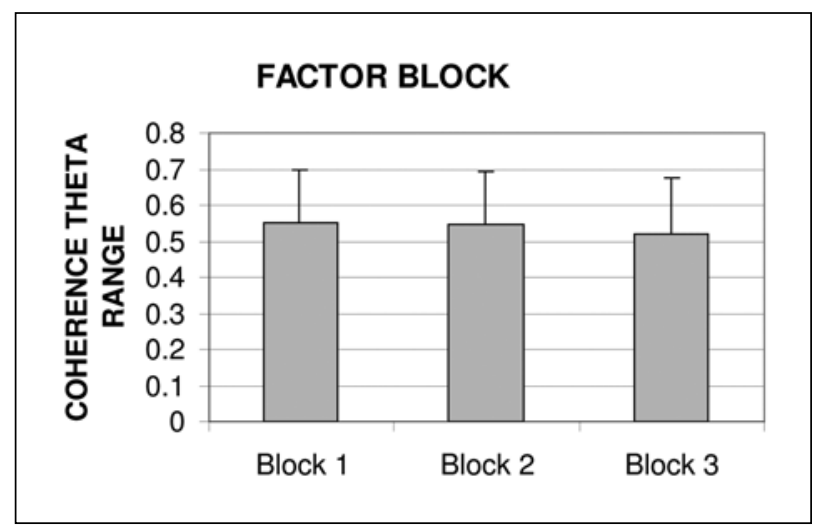

Fig 2. Relation of the coherence values at theta band in prefrontal region between the blocks motor task execution.

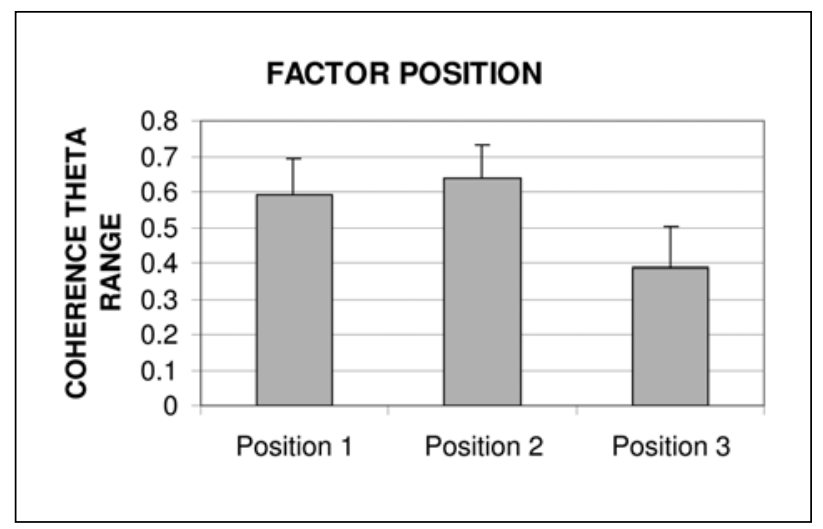

Fig 3. Relation of the coherence values at theta band, between the positions: 1 (left frontal hemisphere), 2 (right frontal hemisphere) and 3 (interhemispheric).

position, a reduction in the coherence measures was observed, being inversely proportional to the distance among them ( $p=0.000)$ (Fig 4).

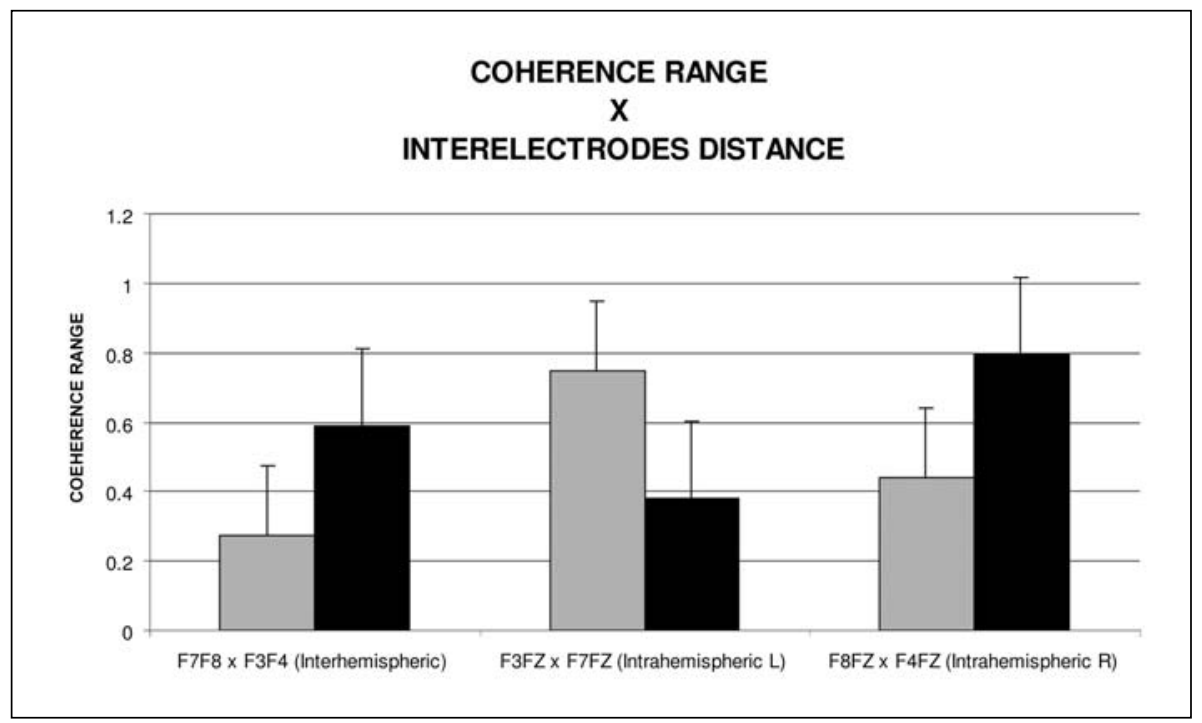

Fig 4. Relation of the coherence values at theta band in prefrontal region and the distance between the electrodes pairs. 


\section{DISCUSSION}

The aim of the present study was to observe electrophysiological changes, through qEEG, in subjects submmitted to a motor task of sequential aprehension of a falling object. The paradigm utilized here was described in previous studies ${ }^{21}$ in which the subjects also carried out a motor task of ball aprehension ( $9 \mathrm{~cm}$ diameter) released by an eletomagnetic instrument. The balls fell off different heights (0.2$1.2 \mathrm{~m}$ ) at a randomized time (1-4.5 sec) after a sound warning. The muscular activity of the biceps, triceps, flexor carpi radialis, flexor carpi ulnaris, extensor carpi radialis and ulnaris were acquired through electromyography (EMG), by surface electrodes ${ }^{21}$. Data previously registered as for Lacquaniti and Maioli (1989), and Lang and Bastian $(1999,2001)$ showed only electromyographic activity, while our study observes also electrocortical activity ${ }^{21}$.

In the present study, the analysis of the electroencephalographic variables has considered particularly the coherence measure, which is the covariance of spectral power at specific frequency bands among electrode pairs throughout the scalp ${ }^{11-13}$. The variation observed at coherence suggests a functional evidence of co-activatioan between the two cortical areas $^{12}$. The reduction on coherence might be an indicative of specialization of certain cortical areas, which could be translated into learning ${ }^{15}$. At theta, the following analysis was carried out: time (pre e post-aprehension) $x$ blocks $x$ scalp position left frontal (F7F3; F7FZ E F3FZ), right frontal (F8F4; F8FZ and F4FZ) and inter-hemisphere (F7F8; F3F4; F7F4 and F8F3). No interaction between the factors was observed. Therefore, the discussion is divided among the main effects of the three factors.

Factor time - Coherence, detected two seconds after the ball release, has shown a significant increase comparing the two seconds before the ball release. Studies suggest that during the accomplishment of a motor task (finger movements), an intrinsic and hierarquical cortical coupling might occur among interconnected regions, activated by similarly during the observation and execution of movements ${ }^{22}$. In the present study, the subjects, first observed the falling of the object (ball) and than catched it immediatly. Both tasks (observing and catching), occured in the post-release time. The increase in coherence during the post-release time seems to be originated by the accumulation of tasks involved in the process. Particularly, the cognitive and motor tasks necessary for the ball catching and release. All these processes occurred within the 2 seconds after the ball release by the system. Such planning and expectation demands involve specificaly the frontal ${ }^{5-7}$.

Factor block - A coherence reduction from block 1 to block 3 was also observed, suggesting a neuronal specialization observed in individuals exposed to implicit memory tasks. Recent investigations have demonstrated that implicit memory might be related to the inferior frontal gyrus, an area that influences the selected electrodes. Therefore, it is suggested that these areas (frontal) retain information on motor procedures, although such mecanisms are not yet elucidated ${ }^{23,24}$. This is well observed in models involving sequential motor tasks, in which coherence measures among cortical areas are high at the beggining of the task, and reducted as the movement is frequently repeated. Probably, the pre-established areas regarding motor functions are activat$\mathrm{ed}^{25}$. These experiments contribute to the comprehension of differences between times 1 and 3 . In behavioral studies, a reduction in mistakes and execution time during typewriting is also observed ${ }^{26}$. These findings reinforce the hypothesis that the transition from block 1 to 2 seemed to match with some critical stage of learning; setting, perhaps, the evolution from a controlled processing stage (emphasizing on cognitive demands), toward advanced stages, such as automatism (predominantly motor demands).

Factor position - The results also point toward a main effect for the factors position. Coherence measures demonstrate significative differences among the left frontal cortex (LFC), the right frontal cortex (RFC) and the intersection of the two frontal cortices (IFC). In the intra-hemispheric analysis, the LFC presented a reduced coherence among the selected electrode channels. It is relevant to remind that coherence reductions suggest especializations of certain cortical areas, which might be translated into learning ${ }^{15}$. The increase in density/development of short fibers of specialized neural population would promote coherence reduction through the increase in complexity and competition of cell interactions ${ }^{11}$. Since it is the sensory-motor representation of the right limb in the left hemisphere ${ }^{9}$, the LFC would be at a level of advanced neuronal specialization, originating reduced coherence measures, when compared to the RFC. The low inter-hemispheric coherence measures (ICM) might occur due to the fact that it has relations with cortex's long association fibers. Contrarly, in this case, there is an increase in density-development and which decreases systematically with the fiber's height (increase in electrode's distance) ${ }^{11-13}$. Our findings are in agreement with other studies, 
which have demonstrated a smaller coherence value for inter-electrodes long distances (F7F8; F7FZ; F8FZ), and greater coherence values for short distances (F3F4; F3FZ; F4FZ).

In conclusion, our findings are in agreement with the majority of the investigations, in which the coherence reduction occurred: with time execution, at the contra lateral hemisphere to the utilized limb; and with the increase in the distance among electrodes. This suggests a specialization in the neural circuit. New experiments, employing left-handed tasks or high mental load tasks, must be carried out in the future in order to compare the outcomes.

\section{REFERENCES}

1. Ungerleider L, Doyon J, Karni A. Imaging brain plasticity during motor skill learning. Neurobiol Learn Mem 2002;78:553-564.

2. Nargeot R. Votage-dependent switching of sensorimotor integration by a lobster central pattern generator. The J Neurosci 2003;23:4803-4808.

3. Roland P, Larsen B, Lassen N, Skinhoj E. Suplementary motor area and other cortical areas in organization of voluntary movements in man. J Neurophysiol 1980;43:118-136.

4. Kandel ER, Schwartz JH, Jessell TM. Princípios da neurociência, 4.Ed., São Paulo: Manole, 2002.

5. Enoka RM. Bases neuromecânicas da cinesiologia, 2.Ed., São Paulo: Manole, 2000.

6. Takehara-Nishiuchi K, Kawahara S, Kirino Y. NMDA receptor-dependent processes in the medial prefrontal cortex are important for acquisition and the early stage of consolidation during trace, but not delay eyeblink conditioning. Learn Mem 2005;12:606-614.

7. Karni A. The acquisition of skilled motor performance: fast and slow experience-driven changes in primary motor cortex. Proc Natl Acad USA 1998;95:861-868.

8. Hung T, Saarela P, Hatfield B. Eletroencephalography and mental states associated with elite performance. J Sport Ecercise Psychol 1998;20: 35-53

9. Smith M, Mcevoy L, Gevins A. Neurophysiological indeces of strategy development and skill acquisition. Cogn Brain Res 1999;7:389-404.
10. Carvalho-Machado SE, Marques-da-Cunha M, Vale-Bastos VH, et al. Modification of the power distribution according to the consolidation of implicit memory by means of a typing task. Rev Neurol 2005;41: 635-638.

11. Barry R, Clarke A, McCarthy R, et al. Age and gender effects in EEG coherence: II. Boys with attention déficit/hyperactivity disorder. Clin Neurophysiol 2005;116:977-984.

12. Anghinah R, Caramelli P, Yassumasa T, Nitrini R, Sameshina K. Estudo da coerência do eletrencefalograma na banda de freqüência alfa em indivíduos adultos normais. Arq Neuropsiquiatria 2005;63:83-86.

13. Barry R, Clarke A, McCarthy R, Selikowitz M, Johnstone S. EEG coherence adjusted for inter-electrode distance in children with attentiondeficit/hyperactivity disorder. Int J Psychophysiol 2005;58:12-20.

14. Editorial. EEG coherence. Int J Psychophysiol 2005;57:83-85.

15. Andres FG, Mima T, Schulman AE, Dichgans J, Hallett M, Gerloff C. Functional coupling of human cortical sensorimotor areas during bimanual skill acquisition. Brain 1999;122:855-870.

16. Portella C, Silva JG, Bastos VH, et al. Aprendizagem de procedimento e efeitos ansiolíticos: medidas eletrencefalográficas, motora e atencional. Arq Neuropsiquiatr 2006;64:478-484.

17. Smith ME, McEvoy LK, Gevins A. Neurophysiological indices of strategy development and skill acquisition. Cogn Brain Res 1999;7:389-404.

18. Duckrow RB, Zaveri HP. Coherence of the electroencephalogram during the first sleepcycle. Clin Neurophysiol 2005;116:1088-1095.

19. Oldfield R. The assessment and analysis of handedness: the Edingurgh inventory. Neuropsycology 1971;9:97-113.

20. Jasper $H$. The ten-twenty electrode system of theinternational federation. EEG Clin Neurophysiol 1958;10:371-375.

21. Lacquaniti F, Maioli C. Adaptation to suppression of visual information during catching. J Neurosci 1989;9:149-159.

22. Calmels C, Holmes P, Jarry G, et al. Variability of EEG synchronization prior to and during observation and execution of a sequential finger movement. Hum Brain Mapp 2006;27:251-266.

23. Kim Y, Lee B, Shin Y, Kwon J, Kin M. Activity of left inferior frontal gyrus related to Word repetition effects: LORETA imaging with 128channel EEG and infividual MRI. Neuroimage 2006;29:712-720.

24. Thiel A, Haupt W, Habedank B, et al. Neuroimaging-guided rTMS of the left inferior frontal gyrus interferes with repetition priming. Neuroimage 2005;25:815-823.

25. Bastos VHB, Machado D, Cunha M, et al. Medidas eletrencefalográficas durante a aprendizagem de tarefa motora sob efeito do bromazepam. Arq Neuropsiquiatr 2005;63:443-451.

26. Machado D, Bastos VH, Cunha M, Cagy M, Piedade R, Ribeiro P. Efeitos do bromazepam observados pela eletrencefalografia quantitativa (EEGq) durante a prática de datilografia. Arq Neuropsiquiatr 2005; 63:452-458. 